\title{
The Effect of Competence and Motivation of Employee Performance With Organizational Commitment as Intervening Variables in PT. Maleo Kreatif Indonesia
}

\author{
Fatinah Ghiyats ${ }^{1}$, Irfan Noviandy Aulia, Dr., SE., MM., CHRP ${ }^{2}$ \\ ${ }^{1}$ Master of Management, Mercubuana University, Jakarta, Indonesia \\ ${ }^{2}$ Lecturer of Postgraduate, Mercubuana University, Jakarta, Indonesia
}

\begin{abstract}
This study aims to determine and analyze the effect of competence and motivation on employee performance at PT. Maleo Kreatif Indonesia. To find out and analyze the effect of competence, motivation on organizational commitment at PT. Maleo Kreatif Indonesia. To find out and analyze the effect of organizational commitment on employee performance at PT. Maleo Kreatif Indonesia. To find out and analyze the effect of competence and motivation on employee performance with organizational commitment as an intervening variable at PT. Maleo Kreatif Indonesia. The research method in this study uses quantitative research with the type of explanatory research. The population in this study were all employees of PT. Maleo Kreatif Indonesia, amounting to 60 people who are at the level of the manager down. The sample method in this study uses probability sampling by determining the sample using a census. Then the size of the sample used in this study were 60 respondents who were employees with managerial level downwards. The data analysis method used in this study is the Structural Equation Model (SEM) with the help of the Smart PLS version 3 program.
\end{abstract}

The results showed that competence and motivation had a positive and significant effect on employee performance at PT. Maleo Kreatif Indonesia. Furthermore, competence, motivation and have a positive and significant influence on organizational commitment at PT. Maleo Kreatif Indonesia Organizational commitment has a positive and significant impact on employee performance at PT. Maleo Kreatif Indonesia. Competence and motivation have a positive and significant effect on employee performance with organizational commitment as an intervening variable at PT. Maleo Kreatif Indonesia.

Keywords:- Competence, Motivation, Organizational Commitment, Employee Performance.

\section{INTRODUCTION}

Internal and external changes in an organization can be caused by strong or weak contributions from its human resources. Therefore, the existence of human resources in a company can be one of the drivers of company performance. Company performance as an accumulation of performance of all organizational units. Thus, company performance is strongly influenced by three main factors namely organizational support, management capability and the performance of everyone who works at the company.

\begin{tabular}{|c|c|c|c|c|}
\hline Year & $\begin{array}{c}\text { Total } \\
\text { population } \\
\text { (Soul) }\end{array}$ & $\begin{array}{c}\text { Number of } \\
\text { Users } \\
\text { (Soul) }\end{array}$ & $\begin{array}{c}\text { Percentage } \\
\text { of Users }\end{array}$ & $\begin{array}{c}\text { User } \\
\text { Growth }\end{array}$ \\
\hline 2017 & $262,000,000$ & $143,260,000$ & $54.68 \%$ & \\
\hline 2018 & $264,160,000$ & $171,170,000$ & $64.80 \%$ & $18.51 \%$ \\
\hline
\end{tabular}

Table 1:- Penetration of Internet Users in Indonesia

Based on these data, it is known that $64.8 \%$ of the population in Indonesia uses the Internet in their daily lives. The growth was also felt as an opportunity by advertising companies to innovate their business by presenting digital marketing services. This condition also occurs in companies with a core business digital agency. One of the digital agency companies in Indonesia is Maleo. Maleo is a digital advertising agency under the auspices of the Flock Creative Network. 
ISSN No:-2456-2165

\begin{tabular}{|c|c|c|c|c|c|c|}
\hline \multirow[b]{2}{*}{ No. } & \multicolumn{2}{|c|}{2017} & \multicolumn{2}{|c|}{2018} & \multicolumn{2}{|c|}{2019} \\
\hline & $\begin{array}{c}\text { Annual Project } \\
\text { Target }\end{array}$ & $\begin{array}{l}\text { End of Year } \\
\text { Realization }\end{array}$ & \begin{tabular}{|c|} 
Annual Project \\
Target
\end{tabular} & $\begin{array}{l}\text { End of Year } \\
\text { Realization }\end{array}$ & \begin{tabular}{|c|} 
Annual Project \\
Target
\end{tabular} & $\begin{array}{l}\text { End of Year } \\
\text { Realization }\end{array}$ \\
\hline 1 & Ichitan & Ichitan & Mayora - Astor & Indosat UI / UX & $\begin{array}{l}\text { Unilever - } \\
\text { Nameera }\end{array}$ & Nameera \\
\hline 2 & Tokopedia & Tokopedia & DANA & Teh Botol & Sampoerna SRC & Sampoerna SRC \\
\hline 3 & Djarum & Djarum & Indosat UI / UX & $\begin{array}{c}\text { BCA } 360 \\
\text { Campaigns }\end{array}$ & MAP - Marzano & MAP - Marzano \\
\hline 4 & Ahok & Ahok & Teh Botol & XL Prepaid & JTI - Camel & JTI - Camel \\
\hline 5 & Astra Life & Astra Life & $\begin{array}{l}\text { BCA } 360 \\
\text { Campaigns }\end{array}$ & BCA UI / UX & Knots & Knots \\
\hline 6 & & & XL Prepaid & Wings - Tasty & Bytedance & Bytedance \\
\hline 7 & & & BCA UI / UX & Wings - DAIA & Unicef & JetZ \\
\hline 8 & & & Wings - Tasty & BBM & Bytedance & \\
\hline 9 & & & Wings - DAIA & Jokowi & $\begin{array}{l}\text { BCA } 360 \\
\text { Campaigns }\end{array}$ & \\
\hline 10 & & & BBM & UNIQLO & XL Prepaid & \\
\hline 11 & & & Jokowi & Joylab & BCA UI / UX & \\
\hline 12 & & & UNIQLO & Sampoerna & Sampoerna & \\
\hline 13 & & & Joylab & AW & & \\
\hline 14 & & & Sampoerna & 1 Station & & \\
\hline 15 & & & AW & & & \\
\hline 16 & & & CitiBank & & & \\
\hline Total & 5 & 5 & 16 & 14 & 12 & 7 \\
\hline $\begin{array}{r}\text { Percentage } \\
\text { of } \\
\text { achievement } \\
(\%)\end{array}$ & 10 & & 8 & 8 & & 8 \\
\hline
\end{tabular}

Fig 1:- Target Data and Project Realization of PT. Maleo Kreatif Indonesia

Based on these data, it is known that in 2017 PT. Maleo Kreatif Indonesia can complete the annual project perfectly or $100 \%$ realized. However, in 2018 there was a decline in the realization of the target set at the beginning of the year, the decline continued until at the end of 2019 the company was only able to complete $58 \%$ or 7 projects out of a total of 12 projects. Conditions can be made that that PT. Maleo Kreatif Indonesia experienced a decrease in performance, which also has implications for the ability of the resources owned in providing work output that is less than optimal.

The role of human resources for the survival of the company is, of course, undoubtedly, in which human resources play a role in planning performance, implementation, achievement, evaluation and improvement results. The most important factor that can affect the achievement of one's work is the competency factor of the person concerned, especially in digital agencies that have two-way communication characteristics that require human resources, in this case employees who have competence in the field of digital communication.

In addition to competency factors, motivational factors also play an equally important role in digital advertising agencies. This is understandable because motivation is a stimulating force or a force that encourages employees to want to work with different interests between one employee and another employee.

\begin{tabular}{|c|c|c|c|}
\hline No & Factor & Score total & Percentage \\
\hline 1 & Competence & 202 & 50.50 \\
\hline 2 & Motivation & 196 & 49 \\
\hline 3 & $\begin{array}{c}\text { Organizational } \\
\text { Commitment }\end{array}$ & 204 & 51 \\
\hline 4 & Leadership Style & 309 & 77.25 \\
\hline 5 & $\begin{array}{c}\text { Organizational } \\
\text { culture }\end{array}$ & 298 & 74.50 \\
\hline
\end{tabular}

Table 2:- Recap Factors That Affect Employee Performance

There are three factors that are still low in its implementation in influencing the performance of employees of PT. Maleo Kreatif Indonesia and its implementation needs to be evaluated in management, especially human resource management at PT. Maleo Kreatif Indonesia, namely employee competence, work motivation, and organizational commitment. Thus, based on the results of the survey conducted, it can be seen that the conditions of employee competence, work motivation, and organizational commitment at PT. Maleo Kreatif Indonesia is still not optimal so it will have an impact on employee performance in the company. 


\section{THEORETICAL REVIEW}

\section{A. Employee Performance}

Performance is the work achievement of an employee for the tasks and responsibilities given by the organization. Mangkunegara (2015) in Yuningsih and Ardianti's research (2019) employee performance was measured by four dimensions, namely:

$>$ Quality with indicators that are able to work meticulously, able to work deftly, able to reach the standards set, responsive to the task.

$>$ Quantity with indicators that is able to achieve targets, meet predetermined workloads, able to exceed the specified workload, able to work based on the efficiency of time determined by the company.

$>$ Performing tasks with indicators of carrying out tasks is working accurately and there are no mistakes, willing to correct mistakes, able to make decisions and able to participate.

$>$ Responsibility with indicators of responsibility is responsible for what is done, not delaying work, prioritizing the interests of work, maintaining tools, facilities and infrastructure that is responsible.

\section{B. Organizational Commitment}

Organizational commitment is a sense of involvement from within the employee to support all operational activities of the company in order to achieve the goals or vision and mission of the company. Organizational commitment is directly related to emotional involvement, perceptions of risk when leaving the company, and a sense of moral responsibility to continue to support the sustainability of the company. Organizational commitment is measured using three dimensions namely (Sriekaningsih and Setyadi, 2015):

$>$ Affective commitment with indicators of career desire to be organized, trust in the organization, and devotion to the organization.

$>$ Continued commitment with indicators of employee love for the organization, willingness to stay with the job, willing to sacrifice, and personal interests.

$>$ Normative commitment with indicators of loyalty to the organization, happiness in work, and pride in the organization.

\section{Competence}

Competence is the ability of employees to support all their duties and responsibilities while working in an organization. Competence in this case is also a characteristic possessed by employees to help the company's sustainability in achieving its business goals. According to Yuningsih and Ardianti (2019) competence can be measured using three dimensions, namely:

$>$ Knowledge (knowledge). Information held by an employee performs tasks in accordance with the occupied field.

$>$ Skills (skills). Efforts to carry out activities are also responsibilities given by the company properly and optimally.

$>$ Attitude (attitude). Behavioral patterns of doing work and responsibility with company regulations.

\section{Motivation}

Motivation is an encouragement both from within employees and encouragement from outside to continue to spur employees to be productive at work. Motivation in this case is also based on the emergence of needs within the employee to be able to meet those needs. Robbins and Coulter (2007: 131) in Sriekaningsih and Setyadi (2015) there are five dimensions of motivation that refer to Abraham Maslow's hierarchy of needs theory as follows:

$>$ Physiological needs (physiological needs) include hunger, thirst, protection (clothing and housing), sex and other physical needs.

$>$ Safety and security needs, among others, safety and protection against physical and emotional loss.

$>$ Affiliation or acceptance needs (social needs): including affection, ownership, well received and friendship.

$>$ Need or award status includes factors such as respect for self-esteem, autonomy and achievement; and respect for external factors such as status, recognition and attention.

$>$ Self-actualization: the drive to be someone or something in accordance with his ambitions; including growth, the potential for achievement and selffulfillment.

\section{E. Prior Research}

There is previous research on competence, motivation, employee performance and organizational commitment. Yuliantini et.al. (2017) states that competence, motivation and work environment influence organizational commitment and performance. Motivation and work environment indirectly influence the performance of the management of goods through organizational commitment while the effect of HR competence on the performance of the management of goods is not mediated by organizational commitment. Rantesalu et.al. (2016) states that organizational competence and culture have a positive and significant influence on organizational commitment. Work motivation has a negative and not significant effect on organizational commitment. Competence, organizational culture and organizational commitment have a positive and significant effect on employee performance. Rahmi and Wulansari's research (2017) shows that simultaneous and partial employee competence and work motivation have a significant effect on employee performance. Previous research conducted by Saryadi (2017) shows that competency and motivation partially have a positive and significant effect on work commitment. Partially, competence and motivation have a positive and significant effect on employee performance. While work commitment has a significant negative effect on record performance. The path analysis test results show that the direct effect of competence on employee performance.

\section{F. Framework}

Based on the study of theory and previous research on the effect of competence, and motivation on employee performance with organizational commitment variable as an intervening variable, the researcher develops the thinking model as shown below: 


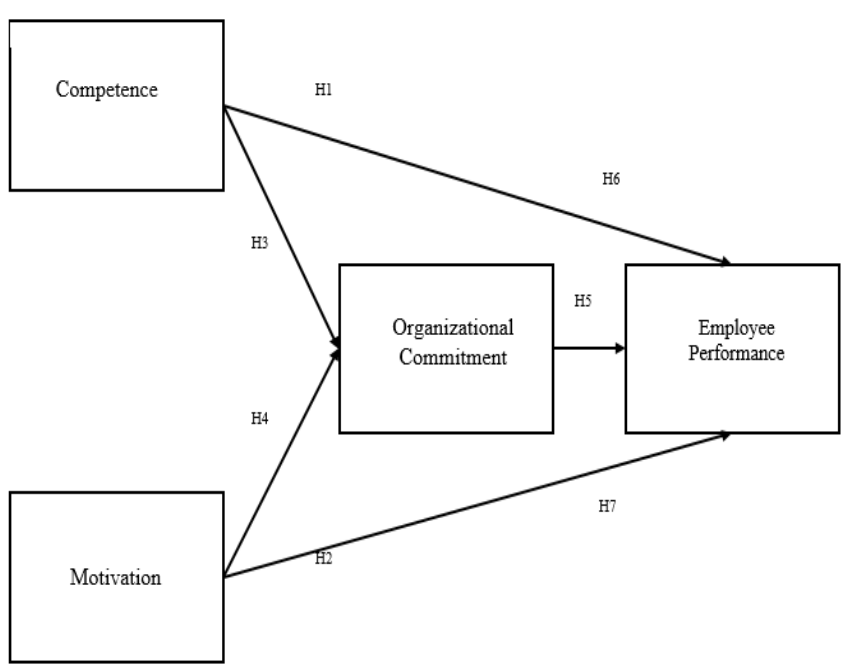

Fig 2:- Conceptual Framework

\section{G. Hypothesis}

Based on deductive reasoning, the relationship between the theoretical framework, the framework of thought and the phenomena that the author wants to adopt in this research is formulated through the following hypothesis:

H1 : Competence has a positive effect on employee performance.

$\mathrm{H} 2$ : Motivation has a positive effect on employee performance.

H3 : Competence has a positive effect on organizational commitment.

H4 : Motivation has a positive effect on organizational commitment.

H5 : Organizational commitment has a positive effect on employee performance.

H6 : Competence has a positive effect on employee performance with organizational commitment as intervening.

H7 : Motivation has a positive effect on employee performance with organizational commitment as an intervening variable.

\section{METHODOLOGY}

This research is included in the type of explanatory research (explanatory research) that there is an implication that the exit or change in one variable causes or leads to changes in the order variable.

\section{A. Population and Research Samples}

The population in this study were all employees of PT. Maleo Kreatif Indonesia, amounting to 60 people who are at the level of the manager down. While the sample method used in this study is probability sampling. Determination of the sample in this study using a census. Then the size of the sample used in this study were 60 respondents who were employees with managerial level downwards.

\section{B. Data Collection Technique}

The source of data in this study is using primary data, obtained from the results of questionnaires. While secondary data in this study were obtained by studying reference books and a number of other literature. The questionnaire used in this study is closed (closed-ended) where the questions given to respondents are in the form of answer choices. So, this type of questionnaire respondents were not given the opportunity to issue opinions.

\section{Data Analysis Method}

This study uses the Structural Equation Model (SEM) approach with measurement models using the Smart PLS version 3 program to measure the intensity of each research variable and the structural model analyzes data and research hypotheses. This is so that researchers can analyze latent variables, indicator variables and measurement errors directly (to find out how the research variables affect each other).

\section{RESULTS AND DISCUSSION}

\section{A. Statistical Description Analysis}

The competency variable has a minimum value of 1.00 , and a maximum of 3.33 with an average score of 2.1617 and a standard deviation of 0.49453 . Furthermore motivation variable has a minimum value of 1.20 , and a maximum of 3.10 with the acquisition of an average value of 2.1750 and a standard deviation of 0.44403 . While the employee performance variable has a minimum value of 1.25 , and a maximum of 3.63 with an average value of 2.2168 and a standard deviation of 0.52667 . Then, the variable organizational commitment has a minimum value of 1.11, and a maximum of 3.56 with the acquisition of an average value (mean) of 2.1215 and a standard deviation of 0.52124 .

\section{B. Hypothesis Test}

In testing inferential statistical data, the data used came from 60 questionnaires. The 60 respondents' data were then processed using the SmartPLS statistical program version 3.3. After importing the data, the researchers then modeled the SmartPLS program version 3.3 as a basis for the program to carry out the data analysis process.

\section{Inner Model Test Results}

\begin{tabular}{|c|c|}
\hline & R Square \\
\hline Employee performance & 0.882 \\
\hline Organizational Commitment & 0.769 \\
\hline
\end{tabular}

Table 3:- Determination Coefficient Test Results

In this study the determination coefficient test aims to see how much the contribution of competence and motivation variables on employee performance, these results indicate the value of the coefficient of determination of $0.882(88.2 \%)$. Can be interpreted that the existence of competence and motivation variables of $88.2 \%$, while the remaining $11.8 \%$ of employee performance is influenced by other factors outside of this study. 
Then for the organizational commitment model that is influenced by the competence, motivation, and performance of employees obtained a coefficient of determination of $0.769(76.9 \%)$. That is, organizational commitment is formed by the presence of competence, motivation, and employee performance of $76.9 \%$, while the remaining $23.1 \%$ is influenced by other factors outside of this study.

\begin{tabular}{|c|c|c|c|}
\hline & $\begin{array}{c}\text { Original } \\
\text { Sample } \\
(\mathrm{O})\end{array}$ & $\begin{array}{c}\text { T Statistics } \\
(\mid \mathrm{O} / \\
\text { STDEV } \mid)\end{array}$ & $\begin{array}{c}\mathrm{P} \\
\text { Values }\end{array}$ \\
\hline $\begin{array}{c}\text { Competence -> } \\
\text { Employee } \\
\text { Performance }\end{array}$ & 0.227 & 2,529 & 0.012 \\
\hline $\begin{array}{c}\text { Motivation -> } \\
\text { Employee } \\
\text { Performance }\end{array}$ & 0.372 & 3,009 & 0.003 \\
\hline $\begin{array}{c}\text { Competence -> } \\
\text { Organizational } \\
\text { Commitment }\end{array}$ & 0.431 & 3,575 & 0,000 \\
\hline $\begin{array}{c}\text { Motivation -> } \\
\text { Organizational } \\
\text { Commitment }\end{array}$ & 0.476 & 3,874 & 0,000 \\
\hline $\begin{array}{c}\text { Organizational } \\
\text { Commitment -> } \\
\text { Employee } \\
\text { Performance }\end{array}$ & 0.388 & 3,422 & 0.001 \\
\hline
\end{tabular}

Table 4:- Output Analysis Path Coefficient

After analyzing the path coefficient which shows the effect of each independent variable on the direct effect variable, then an analysis on the indirect effect is also performed next. The indirect effect test results can be seen in table 5 as follows.

\begin{tabular}{|c|c|c|c|}
\hline & $\begin{array}{c}\text { Original } \\
\text { Sample } \\
(\mathrm{O})\end{array}$ & $\begin{array}{c}\mathrm{T} \\
\text { Statistics } \\
(\mid \mathrm{O} / \\
\text { STDEV | }\end{array}$ & $\begin{array}{c}\mathrm{P} \\
\text { Values }\end{array}$ \\
\hline $\begin{array}{c}\text { Competence -> } \\
\text { Employee Performance }\end{array}$ & .167 & 2,446 & 0.015 \\
\hline $\begin{array}{c}\text { Motivation -> Employee } \\
\text { Performance }\end{array}$ & .185 & 2,425 & 0.016 \\
\hline
\end{tabular}

Table 5:- Indirect Effect Analysis Output

In this process the determination of the basis for making decisions on the value of $t$ arithmetic. Where $t$ arithmetic is obtained from the value of the analysis of the path coefficient, while $t$ table is obtained by looking at the table of percentage distribution of $t$ based on the significant level and degree of freedom. In this study, for a $95 \%$ confidence level ( $\alpha 0.05$ ), the t-table value for the twotailed hypothesis is 1.96 .

Seeing the results of data processing shown in tables 4 and 5 and the basis for making these decisions, the results of this study can be explained as follows:

$>$ Hypothesis $1(\mathrm{H} 1)$ where there is a positive relationship between competence and employee performance is accepted. This is because the $t$ value is $2.529>1.96$ with a P-Value of 0.012 <alpha 0.05 . That is, competence has an influence on employee performance. The coefficient value is 0.227 which means that the effect is positive. This means that competence has a positive and significant impact on employee performance at PT. Maleo Kreatif Indonesia.

$>$ Hypothesis $2(\mathrm{H} 2)$ where there is a positive relationship between motivation and employee performance is accepted. This is because the calculated $t$ value of $3.009>1.96$ with a P-Value of 0.003 <alpha 0.05 . That is, motivation has an influence on employee performance. The coefficient value is 0.372 , which means the effect is positive. This means that motivation has a positive and significant effect on employee performance at PT. Maleo Kreatif Indonesia.

$>$ Hypothesis $3(\mathrm{H} 3)$ where there is a positive relationship between competence and organizational commitment is accepted. This is because the $t$ value is $3.575>1.96$ with a P-Value of 0.000 <alpha 0.05 . That is, competence has an influence on organizational commitment. The coefficient value is 0.431 which means that the effect is positive. This means that competence has a positive and significant impact on organizational commitment at PT. Maleo Kreatif Indonesia.

Hypothesis $4(\mathrm{H} 4)$ where there is a positive relationship between motivation and organizational commitment is accepted. This is because the $t$ value is $3.874>1.96$ with a $\mathrm{P}$-Value of 0.000 <alpha 0.05 . That is, motivation has an influence on organizational commitment. The coefficient value is 0.476 which means that the effect is positive. This means that motivation has a positive and significant effect on organizational commitment at PT. Maleo Kreatif Indonesia.

$>$ Hypothesis 5 (H5) where there is a positive relationship between organizational commitment to employee performance is accepted. This is because the $t$ value of $3.422>1.96$ with a P-Value of 0.001 <alpha 0.05 . That is, organizational commitment has an influence on employee performance. The coefficient value is 0.388 which means that the effect is positive. This means that organizational commitment has a positive and significant impact on employee performance at PT. Maleo Kreatif Indonesia.

Hypothesis 6 (H6) where there is a positive relationship between competence and employee performance with organizational commitment as an intervening variable is accepted. This is because the $t$ value is $2.446>1.96$ with a P-Value of 0.015 <alpha 0.05 . That is, competence has an influence on employee performance with organizational commitment as an intervening variable. The coefficient value is 0.167 which means the effect is positive. This means that competence has a positive and significant effect on employee performance with organizational commitment as an intervening variable at PT. Maleo Kreatif Indonesia.

$>$ Hypothesis 7 (H7) where there is a positive relationship between motivation and employee performance with organizational commitment as an intervening variable is accepted. This is because the $t$ value is $2.425>1.96$ with a P-Value of $0.016<$ alpha 0.05 . That is, motivation has 
an influence on employee performance with organizational commitment as an intervening variable. The coefficient value is 0.185 which means that the effect is positive. This means that motivation has a positive and significant effect on employee performance with organizational commitment as an intervening variable at PT. Maleo Kreatif Indonesia.

\section{Discussion}

\section{$>$ Competence Influences Employee Performance}

The first hypothesis shows that competence affects the performance of employees of PT. Maleo Kreatif Indonesia. Competence is needed in every process of human resources. The more competencies considered, the more performance will improve. Employee competence consisting of knowledge, ability / skill (attitude), attitude (attitude) adjusted to the field of work needed by the organization, so as to produce employee performance achievement (Budiman et.al., 2016). The results of the study are in line with research conducted by Rahmi and Wulansari (2017) and Saryadi (2017) who find employee competency to have a significant effect on employee performance. That is, the higher the competency that is owned will make the employee's performance also higher.

\section{$>$ Motivation Influences Employee Performance}

The second hypothesis shows that motivation affects the performance of employees of PT. Maleo Kreatif Indonesia. Motivation is also a factor that plays a role in improving performance. Work motivation can provide considerable support in improving work performance, work productivity, and organizational commitment. Motivation will also affect a person's attitude and behavior in carrying out their duties and responsibilities. Strength or weakness of work motivation will determine the level of performance of employees or employees (Yuliantini et.al., 2017). These results are consistent with previous research conducted by Murgianto et al. (2016); Kurniawan et.al. (2018) and Qadir et.al. (2017) states work motivation has a positive effect on employee performance. This shows that the higher the motivation of employees, the higher the tendency for performance to be the motivation of employees. An motivated employee tries to do the work assigned to him.

\section{> Competence Influences Organizational Commitment}

The third hypothesis shows that competence influences organizational commitment at PT. Maleo Kreatif Indonesia. Employees who already have good competence, the company will retain employees to continue working by providing salaries, benefits and others in accordance with their competencies. Appropriate reciprocity between the company and employees who work, making employees will be committed to the company where he works now. These results are consistent with previous studies conducted by Saryadi (2017); Rantesalu et.al. (2016) and Yuliantini et.al. (2017) which shows that competence has a positive and significant effect on work commitment, which means that employees with good and appropriate competencies will be able to understand what needs to be done and what their functions are in the job. A good understanding of the functions and adequate competency of an employee will foster a high commitment to the organization.

\section{$>$ Motivation Influences Organizational Commitment}

The fourth hypothesis shows that motivation influences organizational commitment at PT. Maleo Kreatif Indonesia. The results of this study are supported by the findings of research conducted by Febriani and Suharnomo (2018) which states that work motivation has a positive and significant effect on organizational commitment variables. That is, a good quality of work motivation will encourage someone to stay afloat and provide the best in the organization. The results of this study support by the research of Yuliantini et.al. (2017), Rantesalu et.al. (2016) and Saryadi (2017) who show that work motivation has a positive and significant effect on organizational commitment. This indicates that work motivation has a large influence on employee withdrawal, productivity, and employee turnover. Thus, if work motivation increases, it will further increase organizational commitment.

\section{$>$ Organizational Commitment Influences Employee Performance}

The fifth hypothesis shows that organizational commitment affects the performance of employees of PT. Maleo Kreatif Indonesia. Theories put forward by Robbins and Judge (2008) cited by Yuliantini et.al. (2017) defines commitment as a condition where an individual sits with the organization and its goals and desires to maintain its membership in the organization. This was also supported by Febriani and Suharnomo (2018) who said that the higher the commitment of the employee organization, it would also have an impact on the permanence of employees in the organization and increase employee performance. This research is in line with several previous studies such as Rantesalu et al. (2016), Renyut et.al. (2017); Murgianto et.al. (2016) and Khaerudin et.al. (2018) who found organizational commitment had a positive and significant effect on employee performance.

> Competence Influences Employee Performance With Organizational Commitment As An Intervening Variable

The sixth hypothesis shows that competence influences employee performance with organizational commitment as an intervening variable at PT. Maleo Kreatif Indonesia. According to Hastuti's theory (2018) which states that competence is a basic characteristic of a person that enables issuing superior performance in his work. This result is expected for the company in order to create employee performance, it must strengthen work competence, especially that is the knowledge, attitudes and skills of employees, by means of education and training and creating high employee performance. An employee / employee is required to have competence also has a commitment to the organization in achieving the goals and objectives set. Yuliantini et.al. (2017) explained that having adequate competencies possessed by an employee will foster a high commitment to the organization and have implications for improving employee performance. 
$>$ Motivation Influences Employee Performance With Organizational Commitment As An Intervening Variable

The seventh hypothesis shows that motivation influences employee performance with organizational commitment as an intervening variable at PT. Maleo Kreatif Indonesia. Based on the theory put forward by Febriani and Suharnomo (2018) which states that the determining factor for the creation of organizational commitment is work motivation. In achieving its goals, the company needs to do something so that its human resources want to work as much as possible. One way that employees are motivated to do their jobs is to provide motivation. The higher motivation, the higher the emergence of organizational commitment to the organization which has an impact on the tendency of increasing employee performance. Work motivation can arouse organizational commitment through encouragement to be more involved and actively participate in various organizational activities. When work motivation can generate commitment to the organization, then it will affect employee performance. The results of this study are consistent with previous findings made by Yuliantini et.al. (2017) which states organizational commitment mediates the influence of motivation on performance.

\section{CONCLUSIONS AND SUGGESTIONS}

\section{A. Conclusion}

Based on the results of research that has been done, it can be concluded as follows:

$>$ Competence has a positive and significant effect on employee performance at PT. Maleo Kreatif Indonesia. The results of this study are in line with research by Rahmi and Wulansari (2017) who found that employee competence has a significant effect on employee performance.

$>$ Motivation has a positive and significant effect on employee performance at PT. Maleo Kreatif Indonesia. The results of this study are in line with research by Budiman et al. (2016) states that motivation has a positive and significant effect on employee performance.

> Competence has a positive and significant effect on organizational commitment at PT. Maleo. The results of this study are in line with Saryadi's (2017) study which found that competence had a positive and significant effect on work commitment.

> Motivation has a positive and significant influence on organizational commitment at PT. Maleo Kreatif Indonesia. The results of this study are in line with the research of Yuliantini et.al. (2017) which shows that work motivation has a positive and significant effect on organizational commitment.

$>$ Organizational commitment has a positive and significant impact on employee performance at PT. Maleo Kreatif Indonesia. The results of this study are in line with research by Renyut et.al. (2017) who found organizational commitment had a positive and significant effect on employee performance.
Competence has a positive and significant effect on employee performance with organizational commitment as an intervening variable at PT. Maleo Kreatif Indonesia.

$>$ Motivation has a positive and significant effect on employee performance with organizational commitment as an intervening variable at PT. Maleo Kreatif Indonesia.

\section{B. Suggestion}

Based on the conclusions of the research and statistical testing that has been done, it can be made a research suggestion for the management of PT. Maleo Kreatif Indonesia and for further research:

\section{$>$ For Companies}

It is recommended to the management of PT. Maleo Kreatif Indonesia to pay attention to employee competencies and help improve these competencies by providing training to employees in order to identify existing problems, help improve technical expertise in accordance with the work being handled, provide knowledge to employees about job disk work. In addition, it is recommended to PT. Maleo Kreatif Indonesia in order to increase employee motivation by providing facilities for employee self-development and taking into account the needs of employees' families. It is recommended to the management of PT. Maleo Kratif Indonesia to increase employee commitment by exercising confidence in employees that it is difficult to get a job with a good income. Management of PT. Maleo Kreatif Indonesia is expected to continue to improve employee performance by helping to improve employee competency and motivation.

\section{For Further Research}

Future studies can conduct research by adding several other independent variables such as leadership style, organizational culture, and job satisfaction to which these variables can also add broader results related to factors that determine employee performance. Then, the analysis can be done by adding moderation variables such as age, years of service, and marital status, in order to obtain information on which groups are more likely to get employee development in supporting their performance while at the company.

\section{REFERENCES}

[1]. Bernard C. Renyut, H. Basri Modding, Jobhar Bima, \& Sukmawati 2017, "The effect of organizational commitment, competence on Job satisfaction and employees performance in Maluku Governor's Office", IOSR Journal of Business and Management (IOSR-JBM), e-ISSN: 2278-487X, p-ISSN: 2319 7668. Volume 19, Issue 11. Ver.III (November), PP 18-29.

[2]. Dinda Shara Harum Febriani, \& Suharnomo 2018, "Pengaruh Pengawasan, Motivasi Kerja, Dan Komunikasi Interpersonal Terhadap Kinerja Karyawan Dengan Komitmen Organisasi Sebagai Variabel Intervening", Diponegoro Journal Of 
Management, Volume 7, Nomor 1, Halaman 1-12, ISSN (Online): 2337-3792.

[3]. Erni Yuningsih \& Ardianti 2019, "Pengaruh Kompetensi Dan Motivasi Terhadap Kinerja Pegawai Pada Pt Xxx", Jurnal Visionida, Volume 5 Nomor 1.

[4]. Ghayyur Qadir, Imran Saeed, \& Saif Ullah Khan 2017, "Relationship between Motivation and Employee Performance, Organizational Goals: Moderating Role of Employee Empowerment", Journal of Business and Tourism, Volume 03 Number 01.

[5]. Hastuti, D 2018, "Pengaruh Motivasi, Kompetensi Dan Kepuasan Terhadap Kinerja Kader Kesehatan Dengan Komitmen Kerja Sebagai Variabel Intervening (Studi Puskesmas Pagiyanten Kabupaten Tegal)", Jurnal Magisma, Vol. 6, No. 1, hal. 23-34.

[6]. Khaerudin, Abdul Rivai, \& Muhadi Riyanto 2018, "The Effect Of Placement And Competency On Performance Through Employee Commitment In Financial Center Office Ministry Of Defense Indonesia", IOSR Journal of Business and Management (IOSR-JBM), e-ISSN: 2278-487X, pISSN: 2319-7668. Volume 20, Issue 2. Ver. VIII (February), PP 54-61.

[7]. Kurniawan, D.A., Guswandi, \& Sodikin, A 2018, "The Effect of Competence and Motivation on Employee Performance Through Employees Capabilitieson PT. Binasinar Amity", International Journal Of Research Science \& Managemen, ISSN: 2349-5197.

[8]. Murgianto, Siti Sulasmi, \& Suhermin 2016, "The Effects of Commitment, Competence, Work Satisfaction on Motivation, and Performance of Employees at Integrated Service Office of East Java", International Journal of Advanced Research, Volume 3, Issue -378-396.

[9]. Novelisa P. Budiman, Ivonne S. Saerang, \& Greis M. Sendow 2016, "Pengaruh Kompetensi, Motivasi, Dan Disiplin Kerja Terhadap Kinerja Karyawan (Studi Pada PT. Hasjrat Abadi Tendean Manado)", Jurnal EMBA, Vol. 4, No. 4, hal. 321-332.

[10]. Rahmi, AU., \& Wulansari, P 2017, "Pengaruh Kompetensi Pegawai dan Motivasi Kerja Terhadap Kinerja PegawaiDinas Pendidikan Pemuda dan Olahraga Kabupaten Kuningan", e-Proceeding of Management, Vol. 4, No. 2, hal. 1359-1365.

[11]. Rantesalu, A., Mus, A.R., Mapparenta, \& Arifin, Z 2016, "The Effect of Competence, Motivation and Organizational Culture on Employee Performance: the Mediating Role of Organizational Commitment", Journal of Research in Business and Management, Volume 4 - Issue 9 pp: 08-14, ISSN(Online) : 23473002 .

[12]. Saryadi 2017, "Kompetensi, Motivasi Dan Komitmen Kerja: DampaknyaTerhadap Kinerja Pegawai Rekam Medik(Studi pada RSUD dr. Moewardi Surakarta)", Jurnal Manajemen, Bisnis dan Pendidikan, hal. 27-32.

[13]. Sriekaningsih, A., \& Setyadi, D 2015, "The Effect of Competence and Motivation and Cultural Organization towards Organizational Commitment and Performance on State University Lecturers in East
Kalimantan Indonesia”, European Journal of Business and Management, ISSN 2222-1905, ISSN 2222-2839, Vol.7, No.17.

[14]. Yuliantini, Putu Ayu, I.B. Putra Astika, \& Dewa Nyoman Badera 2017, "Pengaruh Kompetensi Sumber Daya Manusia, Motivasi Dan Lingkungan Kerja Pada Komitmen Organisasi Dan Implikasinya Pada Kinerja Pengurus Barang", E-Jurnal Ekonomi dan Bisnis Universitas Udayana 6.10, 3697-3730, ISSN : 2337-3067. 